\title{
Aneszteziológia és intenzív terápia a Semmelweis Egyetem I. sz. Sebészeti Klinikáján
}

\author{
SZEDLÁK BALÁZS, DARVAS KATALIN, SZIJÁRTÓ ATTILA
}

Semmelweis Egyetem, I. sz. Sebészeti Klinika, Budapest

\section{Az aneszteziológia rövid története}

Az aneszteziológia, a mütéti érzéstelenítés története elválaszthatatlan a társszakmák történetétől, hiszen az ő igényeik hívták életre, s tették szükségességé a különböző mütéti eljárásokhoz alkalmazható érzéstelenítési módszereket, valamint azok fejlődését.

Ugyan az első altatáshoz használt édes vitriolt, azaz étert már 1275-ben a híres spanyol alkimista, Raimundus Lullus felfedezte, sőt 1605-ben a svájci Paracelsus is alkalmazta fájdalomcsillapítás céljából, valódi rendeltetését azonban csak évszázadokkal később nyerte el. A nitrogénoxidul 1772-ben Joseph Pristley, angol vegyész újítása volt, aki nem ismerte fel találmánya érzéstelenítő hatását, azt csak 1800-ban Humphrey Davy (akitől a „nevetőgáz” elnevezés is származik) írta le.

Az első nyilvános és azonnali sajtó visszhangot kapó narkózist egy amerikai fogorvos, William Thomas Green Morton végezte, aki saját fejlesztésű adagolójával sikeres éternarkózist végzett 1846. október 16-án egy állkapocsdaganat eltávolításához. Az éter ezt követően sokáig egyeduralkodó volt az általános érzéstelenítés területén. Az aneszteziológia további fejlődéséhez részben újabb gyógyszerek - általános érzéstelenítésre kloroform, halothan, isofluran, sevofluran, desfluran; helyi, illetve regionális érzéstelenítésre kokain, lidokain, prokain, prilokain, artikain, bupivakain, ropivakain -, részben újabb módszerek felfedezése - endotraheális intubálás (1880: Macewan, 1919: Magill, 1926: Gudel), epidurális (1885: Corning) és spinális érzéstelenítés (1898: Bier) - járult hozzá, s a technikai fejlődés eredményeként az első orvosi lélegeztető készüléktől (1904) és újralélegeztető altatógéptől (1924) eljuthattunk a ma használatos, többparaméteres monitorizálást is biztosító lélegeztetö- és altatógépekig.

A magyar vonatkozások tekintetében kiemelt jelentőségü, hogy Balassa János, a Pesti Királyi Tudományegyetem sebész tanára, 1847. február 11-én éternarkózisban („kénégennyel”) végzett hydrokele műtétet, csupán 4 hónappal Morton bostoni altatása után. Másnap a Rókus Kórházban Flór Ferenc már szintén éteres altatásban operált. 1847. március 9-én a Pesti helytartótanács kötelezővé tette okleveles orvos jelenlétét éter anesztézia során. Az 184849-es forradalom és szabadságharc volt az első olyan, Európában viselt háború, ahol a sebesülteket éter és kloroform anesztéziában látták el. 1949 áprilisában történt az első endotraheális intubálással végzett anesztézia Budapesten. 1958-ban a Magyar Sebészeti Társaság megalapította Anesztézia munkacsoportját, majd 1966-ban megalakult a Magyar Aneszteziológiai és Intenzív Terápiás Társaság.

\section{Aneszteziológia és intenzív terápia a Sebészeti Klinikán}

A mütéti érzéstelenítéssel kapcsolatos adatok a Klinika első 50 évéből csak szegényesen maradtak fenn. Az inhalációs anesztézia mellett helyi érzéstelenítést és ópiát analgéziát alkalmaztak. Az 1950-es évek második felétől vezették be a korszerünek számító mütéti érzéstelenítést a Hedri Endre sebész professzor által vezetett klinikán, melyet akkor még sebészek végeztek. A mütétek döntő többségéhez lokális anesztéziát, a baleseti sebészetben pedig „lumbális” érzéstelenítést alkalmaztak. A mütéti érzéstelenítés, majd az intenzív terápia fejlődését a sebészeti profilok határozták meg, és a korszerü sebészeti eljárások bevezetése, az új aneszteziológiai és intenzív terápiás eljárások, technikák és gyógyszerek alkalmazása tette lehetővé. Az 1950-es évek végétől vezették be az endotraheális intubálást, az eredetileg sebészként ténykedő Csernohorszky Vilmos az elsők között tette le az aneszteziológiai szakvizsgát, a 60-as évek elején. Később a megalakuló Aneszteziológiai Társaság meghatározó egyénisége, főtitkára lett.

Ebből az időszakból külön kiemelendő, hogy az Orvos-egészségügyi Szakszervezet Sebész Szakcsoportjának 1955. évi Nagygyülésén, melynek fö témája a műtéti érzéstelenítés volt, Szécsény Andor, Kokas Ferenc és E. Szabó László a mütéti hibernációval szerzett tapasztalatairól, $R u$ bányi Pál a helyi érzéstelenítés mellkassebészetben betöltött szerepéről, Keltai Pál pedig egy új izomrelaxáns használatáról tartott előadást.

A Klinikán az általános sebészeti profil mellett mellkassebészeti és baleseti sebészeti osztály is müködött. $\mathrm{Az}$ általános érzéstelenítést a 60-as évektől Csernohorszky adjunktus vezetésével, az akkori gyakorlatnak megfelelően, kezdetben alapképzésben részesült öt-hat sebész végezte. Az első altatógépek a Vöröskereszt 1956-os adományaként kerültek a Klinikára. Rubányi Pál professzor vezetése alatt, 1963-ban az aneszteziológus csapat tovább bővült, az akkor 
érkező Megyaszai Sándor adjunktus 1967-től az aneszteziológiai részleg vezetője lett, munkássága kiemelkedő volt mind a betegellátás, mind az oktatás és a kutatás területén. A betegek mütéti előkészítését Keltai Pál belgyógyász docens segítette, szemléletét később az aneszteziológiai szakma is átvette.

Az 1960-as évek második felétől már hat fóállású aneszteziológus dolgozott a Klinikán, s velük olyan szakképzett, nagy tapasztalatú asszisztensnők, akiktől nem csupán az anesztéziát elsajátító sebészek, hanem a pályakezdő aneszteziológusok is a szakma gyakorlati alapjait tanulták.

Az 1960-as években a súlyos állapotú betegek kezelése egy négy-, majd ötágyas örző osztályon történt. Az itt dolgozó nővérek közül a 70-es években többen elvégezték az intenzív szakápoló képzést. A Klinika már ekkor részt vett a szakorvos képzésben, az aneszteziológus asszisztensek és az intenzív szakápolók képzésében. A 60-as évek végén az örzőből hat, majd tíz és 1972-től 12 ágyas intenzív osztály lett. Az 1970-es évek elejétől a Szécsény Andor professzor által vezetett klinika profiljának megfelelően a gasztrointesztinális sebészet kardia- és nyelőcsőmütött betegei, az endokrin sebészet operáltjai mellett a politraumatizáltak intenzív ellátása is itt történt. A 70-es évektől a lélegeztető géppark jelentősen bővült, megérkezett az első vérgázanalizátor is. Az aneszteziológiai és intenzív terápiás profil az akut pankreatitisz ellátásával, később a Flautner Lajos által vezetett hasnyálmirigy-sebészettel, 1973-tól Perner Ferenc által vezetett veseátültetéssel, majd a 70-es évek végén a Kupcsulik Péter által vezetett heveny nyelőcsővisszér vérzett, májelégtelen betegek intenzív ellátásával bővült.

1973 novemberében történt Klinikánkon az első veseátültetés, az ezt követő több mint 600 beteg mütéti előkészítése, az anesztézia, majd a mütét utáni intenzív terápia, az immunszuppresszió, a hemo- és peritoneális dialízis egyaránt jelentős szakmai kihívást és előrelépést jelentett. $\mathrm{Az}$ addig alkalmazott vénapreparálást felváltotta a centrális vénakanülálás és általánossá vált a centrális vénás nyomás mérése. 1975-től a Klinika Aneszteziológiai és Intenzív Terápiás Osztályát Darvas Katalin professzor asszony vezette (adjunktusi, majd docensi és 1991-től egyetemi tanári beosztásban), helyettese Tarjányi Mária, majd Csomós Ákos volt.

1983-ban sokéves elökészületet követően megvalósult az első májátültetés Szécsény Andor professzor vezetésével, Faller József és Kupcsulik Péter részvételével egy 12 éves kislány kapott új májat. A továbbiakban még három májátültetés történt a Klinikán. A 90-es évektől a sebészeti profil Flautner Lajos professzor, majd Kupcsulik Péter professzor és Harsányi László professzor vezetésével tovább bővült, a máj-, pancreas- és nyelőcsősebészet mellett újonnan indított minimálinvazív, laparoszkópos sebészeti ellátás az epehólyag- és lágyéksérvmütéteket, a rekeszizomsérv, a lép, a vakbél, a mellékvese, továbbá a vastag- és vékonybél-operációkat is magába foglalja. Az aneszteziológiai ellátás ezzel párhuzamosan fejlődött, előtérbe került a ma már rutinnak számító többparaméteres betegészlelés. Négyágyas ébredőszoba került kialakításra, mely a személyi és tárgyi feltételek tekintetében jelentős előrelépést jelentett a betegbiztonság vonatkozásában.

Az 1994-ben az önálló Transzplantációs és Sebészeti Klinikára elköltözött transzplantációs profil helyett 1996tól érsebészeti ellátás indult a Klinikán elsősorban carotis-, perifériás verőér- és hasi nagyérmütétek formájában, perioperatív szemléletü aneszteziológiai gyakorlatot igényelve.

1998-ban új intenzív osztály, három mütőből álló új mütőblokk és ébredőszoba került átadásra, melyek már a XXI. század színvonalát jelentették. Az intenzív részleg egy 12 ágyas, központi monitorrendszerrel, modern intenzív ágyakkal és lélegeztetőgépekkel felszerelt, két egyágyas elkülönítő szobával rendelkező egység lett, a mütőkbe korszerü, többparaméteres monitorizálást lehetővé tevő altatógépek kerültek. Az intenzív osztályos ápolást lelkes és szakképzett ápolói csapat végzi, munkájukat a Klinika gyógytornászai egészítik ki. 2012-től Borsodi Mariann, majd Bokor Livia kapott osztályvezetői megbízást, 2018tól Szedlák Balázs az osztályvezető fóorvos.

$\mathrm{Az}$ aneszteziológiai ellátás komplexitását az aneszteziológiai, illetve a fájdalomambulancia teszi teljessé. Az orvosi létszám függvényében a rendelési idők számos alkalommal változtak, a cél a mütétre kerülő teljes beteglétszám preoperatív vizsgálata, valamint döntően a tumoros beteg fájdalomterápiás ellátása.

\section{Az oktatás és kutatás aneszteziológiai vonatkozásai}

A Klinikán dolgozó aneszteziológusok az egyetemi graduális és a posztgraduális orvosképzésben, gyógyszerészképzésben, az aneszteziológus asszisztensi és az intenzív ápolói szakképzésben elméleti és gyakorlati oktatás formájában is részt vesznek. Előadásokat tartanak a szakma országos kongresszusain, szakmai továbbképző tanfolyamokon. Saját szervezésü továbbképző tanfolyamokat tartottak az intravénás és inhalációs anesztézia, egynapos sebészeti anesztézia, fájdalomcsillapítás, mütéti előkészítés és kivizsgálás, az endokrinbetegek, illetve az idős betegek perioperatív ellátása, és a mesterséges táplálás témakörében. A Klinika aneszteziológiai munkacsoportja klinikai gyógyszerkipróbálásokban is részt vett.

Kutatási témáink az endokrinbetegek és az idős betegek sebészeti ellátását, az ambuláns, az egynapos és a minimál invazív mütétek aneszteziológiai ellátását, a posztoperatív fájdalomcsillapítást, a volumenstátusz preoperatív ultrahangos vizsgálatát, valamint a szepszis és a többszervi elégtelenség intenzív terápiáját is magukban foglalják. Ezen területekről számos doktori értekezés, valamint szakdolgozat, rektori pályamunka, tudományos diákköri előadás, hazai és nemzetközi közlemény, tudományos előadás, könyv és könyvfejezet jelent meg.

Az elmúlt évtizedekben a Klinika aneszteziológusai aktívan részt vettek a Magyar Aneszteziológiai és Intenzív 
Terápiás Társaság, az Aneszteziológiai és Intenzív Terápiás Szakmai Kollégium, az Országos Aneszteziológiai és Intenzív Terápiás Intézet, az Egészségügyi Tudományos Tanács bizottsági munkájában, valamint az országos szakfelügyeleti tevékenységben.

Az Aneszteziológiai és Intenzív Terápiás Osztály munkatársai munkájukért 2009-ben, 2013-ban és 2015-ben is megkapták az egészségügyi miniszter Elismerő Oklevelét.

\section{Napjaink és jövőbeni terveink}

Az aneszteziológia ma már inkább perioperatív medicinaként definiálható, hiszen a mütéti altatás mellett a mütétre kerülő betegek kivizsgálása és előkészítése, valamint a posztoperatív intenzív terápia egyaránt a napi munka része. Mindez kiegészül a procedurális szedációval, az akut és a krónikus fájdalmak kezelésével, valamint az infektológiai és táplálásterápiás konzíliumokkal. Klinikánkon a legnagyobb perioperatív ellátási igénnyel a hasnyálmirigy-, a máj- és a nyelőcsőmütétes betegek, valamint a szeptikus állapotú páciensek bírnak, komplex ellátásukhoz a teljes terápiás eszköztár biztosított.

Az átlagos éves mütői anesztéziaszám az utóbbi 10 év (2010-2019) távlatában 3659 (3237-3900) volt.

Az intenzív osztályon kezelt betegek száma ugyanezen időszak alatt évente átlagosan 876 (665-1156) volt.

A jövőre nézve cél az Aneszteziológiai és Intenzív Terápiás Osztály dolgozói létszámának stabilizálása, fejlesztése, szakmai szempontból a szervpótló kezelések bevezetése, a Klinika idei teljes gasztroenterológiai profillal való bővülése kapcsán felmerülő új igények kielégítése, az aneszteziológiai ambulancia és a fájdalom-szakrendelés kapacitásának bővítése, valamint az Aneszteziológiai és Intenzív Terápiás Klinikával való szorosabb szakmai és oktatási kapcsolat kiépítése.

\section{Orvosaink (2020)}

Dr. Szedlák Balázs osztályvezető főorvos

Dr. Darvas Katalin professor emerita

Dr. Özse Márta

Dr. Bán Bence

Dr. Pinkola Krisztina

Dr. Bokor Livia

Dr. Soós Sándor PhD

Dr. Bozó Anna

Dr. Szabó Marcell
Dr. Földes Noémi
Dr. Szücs Orsolya
Dr. Héjja Mária
Dr. Tarjányi Mária $\mathrm{PhD}$
Dr. Horváth Alexandra
Dr. Varga Balázs
Dr. Leél-Össy Eszter

\section{Korábbi kiemelkedő munkatársaink}

Dr. Antony Piroska (részlegvezető föorvos), dr. Bobek Ilona $\mathrm{PhD}$ (osztályvezető föorvos), $d r$. Borsodi Marianna (részlegvezető adjunktus), $d r$. Budai Erika (föorvos), prof. $d r$. Csomós Ákos PhD (osztályvezető föorvos), $d r$. Petróczy Györgyi (osztályvezető főorvos), dr. Réti Katalin (osztályvezető föorvos), $d r$. Szabó Krisztina (részlegvezető föorvos)

\section{Vezető aneszteziológus asszisztenseink (időrendben) \\ Wágner Éva \\ Tihanyiné Balassa Rozina \\ Csabáné Horváth Zita \\ Karády Györgyné \\ Barócsy Katalin \\ Köviné Drabb Judit}

\author{
Vezető intenzív ápolóink (időrendben) \\ Móniné Katus Márta \\ Tóth Vera \\ Major Erika \\ Kollárné Túri Zsuzsanna \\ Huszák Vanyová Kitti
}

\section{Irodalomjegyzék}

Darvas K: Aneszteziológia - intenzív terápia. In: Kupcsulik Péter (szerk.): Az Üllői úti Sebészeti Klinika 19092009. Semmelweis Kiadó, Budapest, 2009; 79-83.

Megyaszai S: Anesztézia (személyes emlékek). In: Kupcsulik Péter (szerk.): Az Üllői úti Sebészeti Klinika 19092009. Semmelweis Kiadó, Budapest, 2009; 85-86.

Friedman $M$, Friedland $G W$ : Crawford Long és a sebészeti érzéstelenítés. In: A tíz legnagyobb orvosi felfedezés. Kossuth Kiadó, Budapest, 2001; 92-111.

Korbuly Gy: Adatok az aether-narkosis magyarországi történetéhez. In: Bogár Lajos (szerk.): Az önálló magyar aneszteziológia és intenzív terápia első 50 éve: 1958 2008. Semmelweis Kiadó, Budapest, 2008; 15-19.

A cikk a Creative Commons Attribution 4.0 International License (https://creativecommons.org/licenses/by/4.0/) feltételei szerint publikált Open Access közlemény, melynek szellemében a cikk bármilyen médiumban szabadon felhasználható, megosztható és újraközölhetö, feltéve, hogy az eredeti szerző és a közlés helye, illetve a CC License linkje és az esetlegesen végrehajtott módosítások feltüntetésre kerülnek. (SID_1) 